\title{
Kindfull-Digital Character Book Effectiveness: A User Satisfaction Approach
}

\author{
Azmi Fitriati $^{1^{*}}$, Subuh Anggoro ${ }^{2}$, Sri Harmianto ${ }^{2}$, Naelati Tubastuvi ${ }^{3}$ \\ ${ }^{1}$ Department of Accounting, Universitas Muhammadiyah Purwokerto, Purwokerto 53182, Indonesia \\ ${ }^{2}$ Department of Preservice Elementary Teachers, Universitas Muhammadiyah Purwokerto, Purwokerto 53182, Indonesia \\ ${ }^{3}$ Department of Management, Universitas Muhammadiyah Purwokerto, Purwokerto 53182, Indonesia
}

Corresponding Author Email: azmi.fitriati@gmail.com

https://doi.org/10.18280/isi.260509

Received: 15 November 2020

Accepted: 19 October 2021

\section{Keywords:}

end-user computing satisfaction, kindfulldigital character book, system quality, user competence, user satisfaction

\begin{abstract}
This study aims to examine the effect of user competence on system quality and user satisfaction with the use of the kindfull-digital character book apps. The quality of the system is measured by indicators of flexibility and accessibility. Then, user satisfaction affected the acceptance of a system. Survey method with quantitative measurements were used. Respondents where users of the application include teachers' and parents. Data were collected using a questionnaire. The analysis technique used is Structural Equation Modeling - Partial Least Square. The results showed that user competence had an effect on system quality. Then, competent users improve system quality. Furthermore, the quality of the system can increase user satisfaction. Satisfied users will always use IS. Thus, resulted monitoring will also be more accurate, complete and timely. Based on these results, were suggested to increase the user's knowledge and skills. So, the quality of the system will improve. The perceived satisfaction will increase their use. Then, application usage training is needed to improve their competence. Thus, the quality of the system can be improved through flexibility and accessibility. The app interface design should be made more userfriendly by providing simple features, compliant content accompanied by interested display.
\end{abstract}

\section{INTRODUCTION}

Character is currently a significant priority in primary education. Character is formed through education, socialization, and interpersonal interactions [1]. Then, character has been shown to improve motivation, performance, self-esteem, self-efficacy, and human relationship quality [2, 3]. Education with character will humanize, open up students' mindsets in achieving their goals, refine reason, tough, mentally strong, and ready for global life challenges.

Most elementary schools have implemented a curriculum that balances academic skills with character development. They have also observed student behavior/activities that foster or strengthen positive character. Each student is monitored on a daily basis using a manual monitoring book. However, this required a significant amount of the class teacher's time and attention.

Manual behavior monitoring influenced students, parents, and teachers to focus solely on the routine of recording and reporting on character activities/indicators implementation. The teacher has been unable to focus on the process of evaluating and improving the character of students in class. As a direct consequence, all of these character activities/indicators are becoming routine. Character education can be successful when someone consistently and spontaneously behaves well, or when it becomes a habit.

Kindfull-digital character book application is an information system used as a character building tool. As database processing, this information system employs an Android-based smartphone application, a website, and a server. Teachers, parents, and students are among the users. This application is intended to track the implementation of student character activities/indicators so that teachers and parents can monitor them.

Information systems should be designed with high flexibility and accessibility. So that it produced information that is faster, more accurate, and real-time This information is required for decision-making [4]. Other advantages include improved service and individual and institutional performance $[5,6]$, as well as more efficient and effective business processes and work routines $[7,8]$.

Users will feel more at ease, less confused, and frustrated if applications are made interactive, flexible, and easily accessible. Technology should not be used to obstruct goal achievement [9]. User satisfaction will be determined by the need for system quality $[9,10]$.

One of the most important indicators of an information system's success is user satisfaction. User satisfaction determines whether a technology or system is accepted or rejected. The greater the impact on user satisfaction, the greater the likelihood of user acceptance [11-13]. There have been few studies that look at user satisfaction when it comes to the implementation of information systems (ERP) [14-19].

This is due to a number of factors influencing user satisfaction. The purpose of this research is to assess the quality of the kindfull-digital character book application using indicators of flexibility and accessibility. System quality can affect user satisfaction, according to DeLone and McLean [11, 12, 20], Vijay [21], and Doll and Torkzadeh [22]. Users will be satisfied if a system is easily accessible and provides information as needed.

The End User Computing Satifaction (EUCS) model was 
developed by Doll and Torkzadeh [22]. The model is used to measure the satisfaction of using information systems. Information systems can be relied upon if they are of good quality and can provide satisfaction to users. With this satisfaction, user acceptance will arise for the information system used.

This study develops the EUCS model [22], which adds user competence as a factor affecting system quality [23-25]. The use of IS quality has an impact on increasing user satisfaction $[11,12,20-22]$. This indicates acceptance of the system.

The implementation of an information system compelled user knowledge and expertise. Without people who understand and are skilled at using the system to achieve organizational goals, IS is rendered ineffective. IS will process data into information based on user commands via a computer program [26]. Trained users can fully utilize IS capabilities [27]. Users who do not understand how to operate and use features in IS will not use them, or will use them incorrectly and optimally. IS is ineligible [25].

The problem addressed in this study is determining the measurement model of user competence, IS quality, and user satisfaction in order to examine the success of IS. Furthermore, it examines how the influence of user competence on IS quality and user satisfaction.

\section{LITERATURE REVIEW}

\subsection{Kindfull-Digital character book}

Kindfull-Digital character book is a character education application used in information systems. The core characters that have been developed are as follows: (1) religious, reflecting faith in God Almighty; (2) nationalist, prioritizing the goals of the nation and state above themselves and their groups; (3) integrity, efforts to be a person who can always be trusted in his words, actions, and work; (4) mutual cooperation, which reflects the act of appreciating the spirit of cooperation in problem solving; and (5) independence, using their energy, thoughts, and time to realize their goals.

Kindfull-Digital character book used web services, android and servers. Applications can request data to web services. Request is forwarded to the server. After the server gives a response, the web services change the data in JSON format, so that it can be read by the android application. The features can be seen Figure 1.

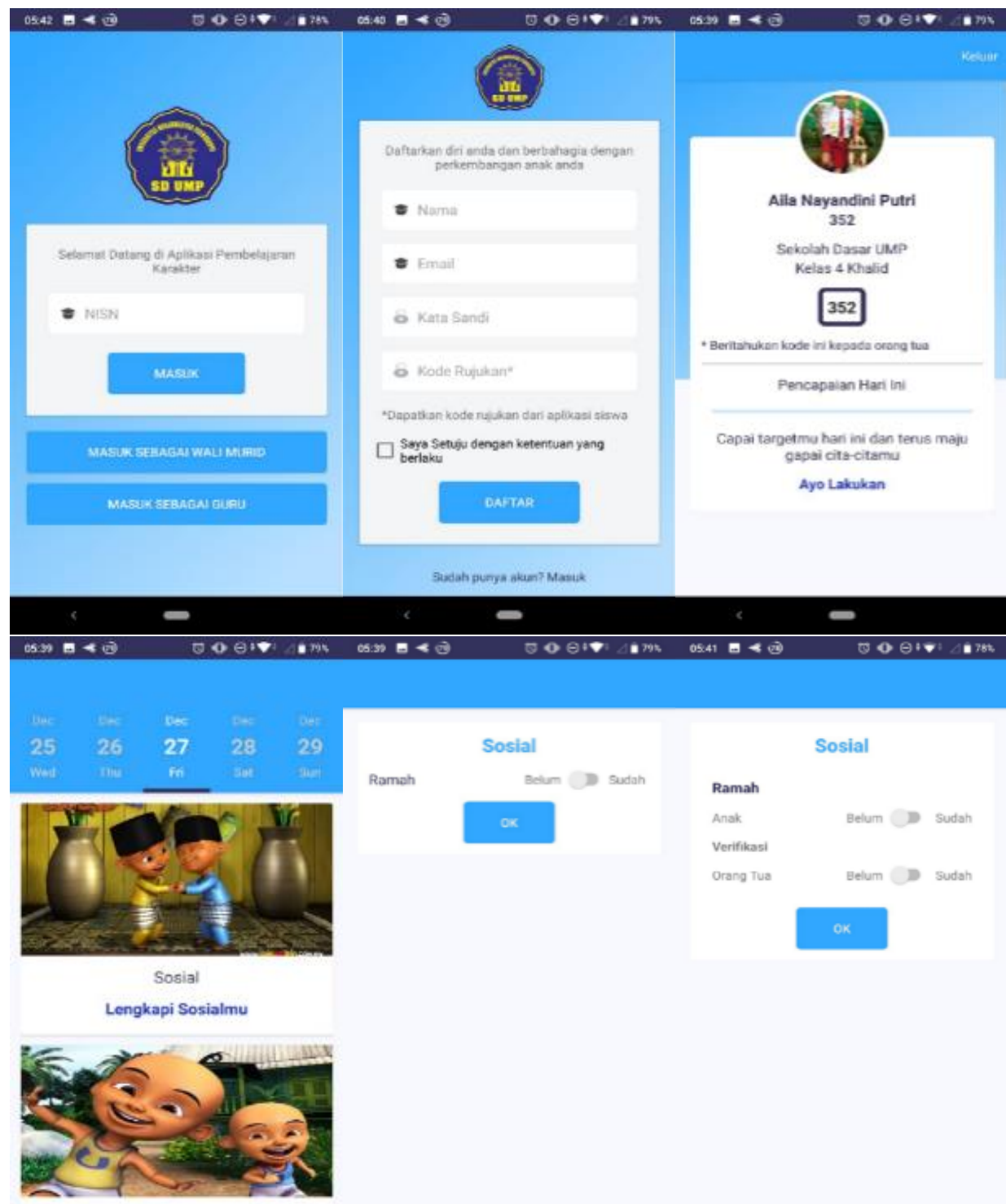

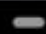

Figure 1. Kindfull app features 
There numbers of hardware and software are used to support the design and development of the kindfull-digital character book application. Table 1 shows the specifications of each device used.

Table 1. Hardware and software specification

\begin{tabular}{cc}
\hline Components & Specification \\
\hline & Intel ${ }^{\circledR}$ Core $\AA$ i7-7700HQ \\
Processor & ( $2.80 \mathrm{GHz}$ \\
& (4 Core $(\mathrm{s})$ 8 Logical \\
Processor(s) \\
Graphics Card & NVIDIA GeForce GTX 1050 \\
Random Access Memory & 8 GB RAM DDR4 \\
(RAM) & 1 TB +256 GB SSD \\
Harddisk & 1920 x 1080 px \\
Resolution & Microsoft Windows 10 Pro 64- \\
Operating System & bit \\
Programming Language & XML, Kotlin \\
IDE & Android Studio 3.5 \\
Android Version & Android 9 (Pie) \\
\hline
\end{tabular}

The implementation of the functions provided is the login function, dashboard page, activity, validation, and reports. Besides, to determine the level of conformity of the system with defined requirements specifications were used validation testing. Testing can be done by comparing the results of the expected use case scenario with the results obtained during the testing process.

\subsection{Effect of user competence on IS quality}

User competence is a basic characteristic of a person related to performance effectiveness [28, 29]. Mathis and Jackson stated that competency components include knowledge, skills, and personality characteristics [30]. Competency aspects include: motives, traits and attitude, self-concept, knowledge, and behaviors, or skills [31].

Gomes-Mejia et al. argued that the competency dimensions include: knowledge, skills and capabilities, work management, character and commitment [32]. The dimensions of competence include knowledge (technical and professional), skills, and personal attributes. Spencer and Spencer stated that the dimensions that form competence are: motives, traits, selfconcepts, knowledge, and skills [28].

Successful IS implementation requires certain knowledge and expertise from users [33]. Users can make the difference between IS implementation success and failure. IS becomes useless without user competence. Users have the knowledge and skills to use the system to achieve goals. IS will work to collect, store and process data into financial information following user orders through computer programs [26].

Users must be properly trained to take full advantage of IS capabilities [27]. When users do not understand the function and operationalization of IS, they cannot use it properly or optimally. This has an effect on the failure of IS implementation [25].

Stair and Reynold have argued that users are an important factor in improving the IS quality [33]. Then, Wahyudi has stated that one of the important factors considered for the successful implementation of IS is a competent user [24]. So, IS success requiring users who have knowledge, experience and technical and managerial skills, including solving problems or obstacles [27].

According to Garg the main problem in IS implementation is related to users [25]. Organizations need to manage change, maintain, communicate and train users to make the most of the system's capabilities. Users must have knowledge and skills to use computers and software.

\subsection{Effect of IS quality on user satisfaction}

Quality IS generated high-quality data. Integration, flexibility, accessibility, formalization, and media richness are among the IS quality dimensions [34]. Meanwhile, according to Romney and Steinbart, usability, economics, dependability, availability, on time, capability, ease of use, flexibility, traceability, and security are all aspects of IS quality [35].

According to Doll and Torkzadeh, IS is qualified if the system can provide user satisfaction [22]. DeLone and McLean [11, 12] stated that system quality affects user satisfaction. User satisfaction is an important measure to ensure the success of IS [36, 37]. Illias et al. state that a reliable and easy to use system will provide user satisfaction [38]. A reliable system shows that the system has the ability to operate without experiencing significant errors and constraints over a long period of time. Furthermore, Illias et al. also explained that using the system makes it easier and faster for someone to complete work than those who do not use it [38].

Based on the literature review, the researcher developed the model formulated by DeLone and McLean $[11,12]$ and Doll and Torkzadeh [22]. According to DeLone and McLean [12], system quality affects user satisfaction. They measured the quality, including flexibility and accessibility. User satisfaction measurement is adopted from Doll Torkzadeh [22]. The model developed by the researcher is shown in Figure 2.

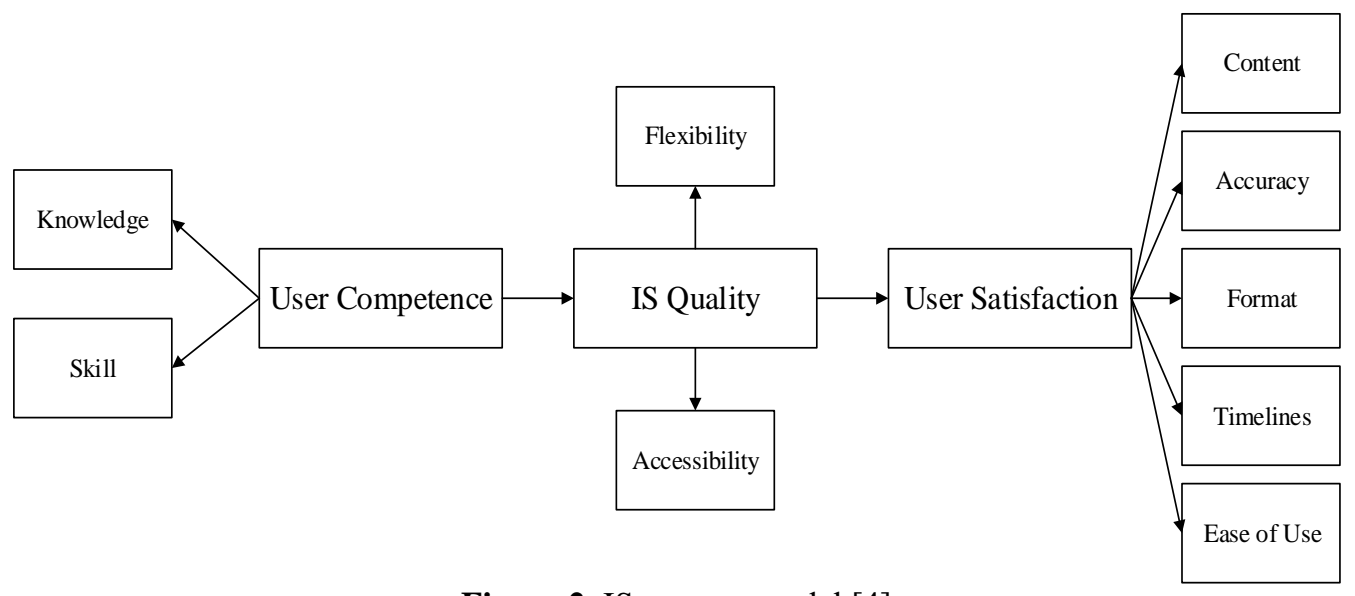

Figure 2. IS success model [4] 


\section{METHODS}

This study uses a survey method with quantitative measurements. Respondents in this study were teachers and parents at a religion private school in Banyumas, Indonesia. Sampling using a purposive sampling method, with the criteria of users who have used the kindfull-digital character book application.

Table 2. Operationalization of variables

\begin{tabular}{|c|c|c|}
\hline Variables & Dimensions & Indicators \\
\hline \multirow{4}{*}{$\begin{array}{c}\text { User Competence }\left(\xi_{1}\right) \\
{[28-30,32]}\end{array}$} & \multirow{2}{*}{$\begin{array}{c}\text { Knowledge } \\
\left(\xi_{2}\right)\end{array}$} & Information seeking $\left(\mathrm{X}_{1}\right)$ \\
\hline & & Technical expertise $\left(\mathrm{X}_{2}\right)$ \\
\hline & \multirow{2}{*}{ Skill $\left(\xi_{3}\right)$} & Analytical skill $\left(\mathrm{X}_{3}\right)$ \\
\hline & & Conceptual skill $\left(\mathrm{X}_{4}\right)$ \\
\hline \multirow{3}{*}{$\begin{array}{c}\text { IS Quality }\left(\xi_{4}\right) \\
{[11,12,33,35,39]}\end{array}$} & \multirow{2}{*}{ Flexibility $\left(\xi_{5}\right)$} & IS's ability to adapt to changing environments $\left(\mathrm{Y}_{5}\right)$ \\
\hline & & IS's ability to customize user needs $\left(\mathrm{Y}_{6}\right)$ \\
\hline & $\begin{array}{c}\text { Accessibility } \\
\left(\xi_{6}\right) \\
\end{array}$ & Ease of access $\left(\mathrm{Y}_{8}\right)$ \\
\hline \multirow{8}{*}{$\begin{array}{c}\text { User Satisfaction }\left(\xi_{7}\right) \\
{[11,12,22,36-38]}\end{array}$} & \multirow{4}{*}{ Content $\left(\xi_{8}\right)$} & Precise information $\left(Z_{9}\right)$ \\
\hline & & Information content meet user needs $\left(Z_{10}\right)$ \\
\hline & & System provides exactly what the user needs $\left(Z_{11}\right)$ \\
\hline & & System provides sufficient information $\left(Z_{12}\right)$ \\
\hline & \multirow{2}{*}{$\begin{array}{c}\text { Timelines } \\
\left(\xi_{11}\right)\end{array}$} & Is the system user friendly? $\left(Z_{17}\right)$ \\
\hline & & Is the system easy to use? $\left(Z_{18}\right)$ \\
\hline & \multirow{2}{*}{$\begin{array}{l}\text { Ease of Use } \\
\left(\xi_{12}\right)\end{array}$} & Do you get the information you need in time? $\left(Z_{19}\right)$ \\
\hline & & Does the system provide up-to-date information? $\left(\mathrm{Z}_{20}\right)$ \\
\hline
\end{tabular}

According to Hair et al. [40], the minimum sample size is determined by power analysis. The type of data used is primary data. The data collection technique used a questionnaire. Respondents' responses were given a rating scale (score 1 to 5 ).

The variables used are user competence, information system quality and user satisfaction. Operationalization of variables as in Table 2.

Table 3. The equation of models

\begin{tabular}{|c|c|}
\hline First orders & Second orders \\
\hline $\begin{array}{l}\mathrm{X}_{1}=\lambda_{12} * \xi_{2}+\delta_{1} \\
\mathrm{X}_{2}=\lambda_{22} * \xi_{2}+\delta_{2} \\
\mathrm{X}_{3}=\lambda_{33} * \xi_{3}+\delta_{3} \\
\mathrm{X}_{4}=\lambda_{43} * \xi_{3}+\delta_{4}\end{array}$ & $\xi_{1}=\lambda_{12} * \xi_{2}+\lambda_{13} * \xi_{3}$ \\
\hline $\begin{array}{l}\mathrm{Y}_{5}=\lambda_{55} * \xi_{5}+\delta_{5} \\
\mathrm{Y}_{6}=\lambda_{65} * \xi_{5}+\delta_{6} \\
\mathrm{Y}_{7}=\lambda_{76} * \xi_{6}+\delta_{7} \\
\mathrm{Y}_{8}=\lambda_{86} * \xi_{6}+\delta_{8}\end{array}$ & $\xi_{4}=\lambda_{54} * \xi_{5}+\lambda_{64} * \xi_{6}$ \\
\hline $\begin{array}{l}Z_{9}=\lambda_{98} * \xi_{8}+\delta_{9} \\
Z_{10}=\lambda_{108} * \xi_{8}+\delta_{10} \\
Z_{11}=\lambda_{118} * \xi_{8}+\delta_{11} \\
Z_{12}=\lambda_{128} * \xi_{8}+\delta_{12} \\
Z_{13}=\lambda_{139} * \xi_{9}+\delta_{13} \\
Z_{14}=\lambda_{149} * \xi_{9}+\delta_{14} \\
Z_{15}=\lambda_{1510} * \xi_{10}+\delta_{15} \\
Z_{16}=\lambda_{1610} * \xi_{10}+\delta_{16} \\
Z_{17}=\lambda_{1711} * \xi_{11}+\delta_{17} \\
Z_{18}=\lambda_{1811} * \xi_{11}+\delta_{18} \\
Z_{19}=\lambda_{1912} * \xi_{12}+\delta_{19} \\
Z_{20}=\lambda_{2012} * \xi_{12}+\delta_{20}\end{array}$ & $\begin{array}{l}\xi_{7}=\lambda_{87} * \xi_{8}+\lambda_{97} * \xi_{9}+\lambda_{107} * \xi_{10}+ \\
\lambda_{117} * \xi_{11}+\lambda_{127} * \xi_{12}\end{array}$ \\
\hline
\end{tabular}

The analysis technique used is Structural Equation Modeling (SEM) based on components or variance using Partial Least Square (PLS). PLS-SEM analysis used in this study consists of two sub models, namely the measurement (outer) and structural (inner) model [40]. The measurement model shows how the manifest or observed variable reflects the latent variable. While the structural model describes the relationship between latent variables based on the substantive theory. Model evaluation in PLS-SEM also consists of two stages.

The equation that shows the causal relationship between indicators and variables in the first and second orders are as Table 3.

Evaluation of measurement models to examine the reliability and validity of latent construct forming indicators [40]. The measurement model in this study is reflective. Evaluations of reflective measurement models include indicator validity, indicator reliability, convergence validity, internal consistency reliability, and discriminant validity. Evaluation of the structural models are to test collinearity, significance of path coefficient, coefficient of determination $\left(\mathrm{R}^{2}\right)$ and effect size $\left(\mathrm{f}^{2}\right)$.

\section{RESULTS}

In this study, the questionnaires were given to parents and teachers who used the kindfull-digital character book application at religion private school in Banyumas, Indonesia. The number of respondents who returned the questionnaire was 136 people. Based on Table 4 the profile of respondents shows that most of the respondents are female (55\%) and young (under 40 years) by $56 \%$, with an undergraduate education level (63\%).

Table 5 showed the average score of user competence and user satisfaction in the high category. Meanwhile, the average score for system quality is in the sufficient category. User competencies is reflected in knowledge and skills. System quality is reflected through the dimensions of flexibility and accessibility. High level of user satisfaction is measured by the availability of information that is in accordance with the content, format, can be provided accurately and in a timely manner and provides ease of use. 
Table 4. Respondents profile

\begin{tabular}{clc}
\hline No. & Characteristics & Percentage \\
\hline 1. & Gender & \\
& Male & $38.2 \%$ \\
& Female & $61.8 \%$ \\
2. & Age & \\
& <40 years & $64.7 \%$ \\
& $>40$ years & $35.3 \%$ \\
3. & Graduates & \\
& High School & $4.4 \%$ \\
& Diploma & $22.1 \%$ \\
& Undergraduate & $61.8 \%$ \\
& Magister & $11.7 \%$ \\
\hline
\end{tabular}

The knowledge and skill dimensions have a high score. It explained that users of the kindfull-digital character book application are well-versed in IS. Users also have strong analytical and conceptual abilities. This makes the application easier to use.

The kindfull-digital character book application used is of sufficient quality, as evidenced by its flexibility and accessibility. As a result, the application has the ability to adapt to changing environments and user needs. The application is also very easy to use both inside and outside of the classroom.

Based on Table 5, it is also known that user satisfaction is also in the high category. This explained that the information generated from the application in terms of content, accuracy, format, timelines and ease of use is in the high category. High quality information provided high satisfaction for users.

Table 5. Score of respondents' responses

\begin{tabular}{|c|c|c|c|c|c|}
\hline Variables & Scores & Categories & Indicators & Scores & Categories \\
\hline \multirow{2}{*}{ User competence } & \multirow{2}{*}{3.54} & \multirow{2}{*}{ High } & Knowledge & 3.57 & High \\
\hline & & & Skill & 3.53 & High \\
\hline \multirow{2}{*}{ IS quality } & \multirow{2}{*}{3.09} & \multirow{2}{*}{ Sufficient } & Flexibility & 3.20 & Sufficient \\
\hline & & & Accessibility & 2.95 & Sufficient \\
\hline \multirow{5}{*}{ User satisfaction } & \multirow{5}{*}{3.55} & \multirow{5}{*}{ High } & Content & 3.49 & High \\
\hline & & & Accuracy & 3.66 & High \\
\hline & & & Format & 3.22 & Sufficient \\
\hline & & & Timelines & 3.74 & High \\
\hline & & & Ease of Use & 3.75 & High \\
\hline
\end{tabular}

Table 6. Fornell-Lacker

\begin{tabular}{lrcccccccc}
\hline & Access & Flex & Know & Skill & Accuracy & Content & EoU & Format & Timelines \\
\hline Access & $\mathbf{0 . 7 7 4}$ & & & & & & & & \\
Flex & 0.731 & $\mathbf{0 . 8 8 0}$ & & & & & & & \\
Know & 0.309 & 0.458 & $\mathbf{0 . 8 5 6}$ & & & & & & \\
Skill & 0.340 & 0.362 & 0.627 & $\mathbf{0 . 9 4 8}$ & & & & & \\
Accuracy & 0.557 & 0.628 & 0.607 & 0.539 & $\mathbf{0 . 8 8 5}$ & & & & \\
Content & 0.423 & 0.552 & 0.607 & 0.609 & 0.741 & $\mathbf{0 . 8 5 1}$ & & & \\
EoU & 0.772 & 0.743 & 0.470 & 0.419 & 0.637 & 0.615 & $\mathbf{0 . 9 6 4}$ & & \\
Format & 0.762 & 0.691 & 0.346 & 0.453 & 0.683 & 0.631 & 0.729 & $\mathbf{0 . 9 3 5}$ & \\
Timelines & 0.476 & 0.579 & 0.473 & 0.537 & 0.738 & 0.853 & 0.561 & 0.658 & $\mathbf{0 . 9 4 3}$ \\
\hline
\end{tabular}

Table 7. Outer loading

\begin{tabular}{|c|c|c|c|c|c|c|c|c|c|c|c|}
\hline \multirow{2}{*}{ Variables } & \multirow{2}{*}{ Dimensions } & \multirow{2}{*}{ Indicators } & \multicolumn{2}{|c|}{ Outer Loading } & \multicolumn{2}{|c|}{ Indicators } & \multirow{2}{*}{$\mathbf{R}^{2}$} & \multirow{2}{*}{ AVE } & \multirow{2}{*}{ CR } & \multicolumn{2}{|c|}{ Dimensions } \\
\hline & & & Estimate & p-value & Validity & Reliability & & & & Validity & Reliability \\
\hline \multirow{4}{*}{$\begin{array}{c}\text { User } \\
\text { competence }\end{array}$} & \multirow{2}{*}{ Knowledge } & Know1 & 0.86 & 0.00 & Valid & Reliable & \multirow{2}{*}{0.78} & \multirow{2}{*}{0.73} & \multirow{2}{*}{0.85} & \multirow{2}{*}{ Valid } & \multirow{2}{*}{ Reliable } \\
\hline & & Know2 & 0.88 & 0.00 & Valid & Reliable & & & & & \\
\hline & \multirow{2}{*}{ Skill } & $\begin{array}{l}\text { Skill1 } \\
\end{array}$ & 0.94 & 0.00 & Valid & Reliable & \multirow{2}{*}{0.86} & \multirow{2}{*}{0.90} & \multirow{2}{*}{0.95} & \multirow{2}{*}{ Valid } & \multirow{2}{*}{ Reliable } \\
\hline & & Skill1 & 0.95 & 0.00 & Valid & Reliable & & & & & \\
\hline \multirow{4}{*}{ IS quality } & \multirow{2}{*}{ Flexibility } & Flex1 & 0.88 & 0.00 & Valid & Reliable & \multirow{2}{*}{0.92} & \multirow{2}{*}{0.77} & \multirow{2}{*}{0.87} & \multirow{2}{*}{ Valid } & \multirow{2}{*}{ Reliable } \\
\hline & & Flex2 & 0.89 & 0.00 & Valid & Reliable & & & & & \\
\hline & \multirow{2}{*}{ Accessibility } & Access 1 & 0.90 & 0.00 & Valid & Reliable & \multirow{2}{*}{0.81} & \multirow{2}{*}{0.54} & & & \\
\hline & & Access 2 & 0.51 & 0.05 & Valid & Reliable & & & 0.681 & Valid & Reliable \\
\hline & & Cont1 & 0.85 & 0.00 & Valid & Reliable & & & & & \\
\hline & & Cont2 & 0.87 & 0.00 & Valid & Reliable & & & & & \\
\hline & Content & Cont3 & 0.81 & 0.00 & Valid & Reliable & 0.84 & 0.72 & 0.913 & Valid & Reliable \\
\hline & & Cont4 & 0.87 & 0.00 & Valid & Reliable & & & & & \\
\hline & A соиноге & Acc1 & 0.91 & 0.00 & Valid & Reliable & & & & & \\
\hline User & Accuracy & Acc2 & 0.86 & 0.00 & Valid & Reliable & 0.75 & 0.78 & 0.878 & Valid & Reliable \\
\hline satisfaction & Format & For1 & 0.93 & 0.00 & Valid & Reliable & & & & & \\
\hline & Format & For2 & 0.94 & 0.00 & Valid & Reliable & 0.70 & 0.88 & 0.933 & Valid & Reliable \\
\hline & Timelines & Time1 & 0.94 & 0.00 & Valid & Reliable & 070 & 0.03 & & Valid & \\
\hline & Timelines & Time2 & 0.94 & 0.00 & Valid & Reliable & 0.19 & 0.93 & 0.941 & Valid & Reliable \\
\hline & $\mathrm{FoU}$ & EoU1 & 0.96 & 0.00 & Valid & Reliable & & 089 & 0963 & Valid & Reliable \\
\hline & EoU & EoU2 & 0.96 & 0.00 & Valid & Reliable & 0.65 & 0.89 & 0.963 & Valid & \\
\hline
\end{tabular}


Table 8. Path coefficient, statistic-t, p-value

\begin{tabular}{ccccc}
\hline \multicolumn{2}{c}{ Variables } & \multirow{2}{*}{ Path coefficient } & \multirow{2}{*}{ Statistic-t } & \multirow{2}{*}{ p-value } \\
\cline { 1 - 4 } Exogenous & Endogenous & & & \\
\hline User competence & IS quality & 0.728 & 5.939 & 0.048 \\
\hline IS quality & User satisfaction & 0.752 & 10.858 & 0.000 \\
\hline
\end{tabular}

Based on the test results, all indicators have an $\mathrm{R}^{2}$ value of 0.5 or more (Table 7). This showed that all indicators meet the criteria of being reliable. According to Hair et al. [40], convergence validity testing is used to test the convergence between indicators in the same construct. This test uses the average variance extracted (AVE) value.

Reliability testing used the composite reliability $(\mathrm{CR})$ value. Based on Table 7, the CR value on all dimensions is more than 0.7. Discriminant validity testing aims to test indicator discrimination when measuring different constructs. Discriminant validity test uses the Fornell-Lacker criterion. Based on Table 6, Fornell-Lacker criterion requires that Fornell-Lacker value of a variable's indicator must be greater for that variable than for other variables [40].

Results of measurement model test showed that measurement models for user competence, IS quality, and user satisfaction have met the criteria for a fit model. All indicators used in this study reflected the latent variables. There are valid and reliable, so they can be used to measure user competence, IS quality, and user satisfaction.

Knowledge and expertise indicators can be used to assess user competence. Then, flexibility and accessibility were used as IS quality indicators. The following indicators are used to assess user satisfaction: format, accuracy, content, ease of use, and completeness.

Structural models that show the relationship between latent variables (exogenous or endogenous) must also be evaluated. Evaluation of it includes path coefficient significance, $\mathrm{R}^{2}$ (coefficient of determination), and $\mathrm{f}^{2}$ test (effect size) [40]. The evaluation results are presented in Tables 8 and 9 .

Table 9. $\mathrm{R}^{2}$ and $\mathrm{f}^{2}$ value

\begin{tabular}{ccc}
\hline Variables & $\mathbf{R}^{\mathbf{2}}$ & $\mathbf{f}^{\mathbf{2}}$ \\
\hline User competence & & 0.420 \\
IS quality & 0.429 & 1.304 \\
User satisfaction & 0.566 & \\
\hline
\end{tabular}

The influence between latent variables can be seen from the path coefficient value. Based on Table 8 , it can be seen that the user competency coefficient value is 0.728 (t-statistical value is 5.939 and the p-value is 0.048 ). This condition can be concluded that statistically, the sample results can significantly illustrate the population results that user competence affects IS quality.

The influence of IS quality on user satisfaction is equal to the coefficient value $(0.752)$ with $t$-statistic value of 10.858 and $p$-value of 0.000 . Since the p-value is less than 0.05 , it can be concluded that at the significance level $\alpha=5 \%$, IS quality also has a positive effect on user satisfaction.

$\mathrm{R}^{2}$ value that explains the variability of endogenous variables that can be explained by exogenous variables. Based on Table 9, the $\mathrm{R}^{2}$ value of 0.429 shows that the variability of IS quality can be explained by changes in the user competency variable which is 0.429 or $42.9 \%$. Other variables outside the study gave an effect of $57.1 \%$. User satisfaction variability explained by changes in the IS quality variable is 0.566 $(56.6 \%)$.

\section{DISCUSSION}

\subsection{Mutual partnership for character education monitoring}

The role of parents in the formation and character education of students is critical, especially at a young age, especially in elementary school $[41,42]$. This position will benefit students' academic and social development [43]. Parental involvement in the educational process helped students develop good character, which supported a fun and meaningful learning environment [44, 45].

Parental involvement in school education has a positive impact on student academic achievement, such as improving student performance and achievement, lowering juvenile delinquency, and decreasing school truancy [46, 47]. Parental involvement in education can take the form of reactive or proactive activities [48]. Visits to schools, attending school invitations, volunteering, and sharing experiences in the classroom through guest speaking are examples of reactive activities.

While the form of proactive activities such as helping with home study activities and monitoring academic, psychological and character development of students. Schools should use these forms of reactive and proactive activities to build mutual partnerships with parents.

Utami et al. created and implemented the Parents Up digital application to encourage parental and teacher collaboration in character development monitoring [42]. This application enables teachers and parents in Indonesia to collaborate to foster and monitor the character education of elementary school students.

Like Parents Up, Kindfull-digital character book were also an application to strengthen character education. The benefits of this app are that the information is provided in realtime and is integrated. As a result, information would be faster, more accurate, and more complete $[11,12]$. As a result, students who require assistance can receive immediate guidance and counseling. When monitoring activities are performed manually, they take a long time, are not flexible, and cannot be handled immediately. The application's critical points in use are ease of operation, flexibility, and accessibility [4].

\subsection{Effect of user competence on IS quality}

In this study, user competence is shown by knowledge and skills as stated by Spencer and Spencer and Taylor [28, 31]. Users who have sufficient knowledge and expertise can more easily take advantage of IS capabilities. So that the increasing knowledge and expertise of users will improve the quality of IS. This is in line with Sedera and Dey which stated the importance of user competence in implementing an effective IS [49]. User knowledge is a necessary factor in implementing IS [50]. The user does not know its function or does not understand how to operate it. They will neither use it nor use it optimally, which can cause IS failure [25]. IS is a tool, so the success of the tool/system depends on the users who can 
use it appropriately or not. Knowledge and skills can increase user competence needed in producing quality information.

The kindfull-digital character book application was designed to adapt to changes and technological developments as well as user needs easily. Application development can be carried out continuously in its use, until the application meets the needs of users who are also constantly developing. As a result, in order for the application to be effective, the user must be prepared to face these changes [51].

The implementation of IS will be optimal if he/she has a high level of confidence in his/her ability to use IS and adapt to changes. Users can immediately resolve problems that arise during the implementation of IS by utilizing the capabilities that they have.

Increasing user competence in IS implementation can improve IS quality in terms of both flexibility and accessibility. Users with advanced knowledge and skills will be able to increase the flexibility and accessibility of IS. Because with increased IS knowledge and skills, the application's facilities and features can be quickly understood, operated, and adapted to changing environments and needs.

Adapting to the use of new technology is not easy. Respondents in this study were dominated by young women (less than 40 years). According to Venkatesh et al., effort expectation on behavioral intention is stronger for women, especially for older women [52]. Besides, Billipp and White and Weatherall revealed that for older man, have tend to less interest using IS [53, 54].

This study succeeded in making a model for measuring user competence that is reflected in the knowledge and expertise. Increasing user competence occurs through continuous improvement of knowledge and expertise. According to Spencer and Spencer [28] user competence is described as an "iceberg model", expertise and knowledge are easily identifiable competency dimensions.

\subsection{Effect of IS quality on user satisfaction}

User satisfaction refers to the extent to which users are satisfied with the use of IS to provide information according to their needs. Determining user satisfaction is important because it can be a measure of success and effectiveness of IS. Kindfull-digital character book application has provided simple features, suitable content accompanied by unobtrusive display colors. Although the application is not fully used because of the customization that does not suit the user's needs. But they stated that they could feel the ease and comfort when using the application.

Kindfull application interface design has been made more user friendly. This gives a positive perception of ease of use [52]. The ease of information obtained in the application also affects the ease with which users feel.

A quality IS provided the complete, accurate, relevant and timely information. It can increase user satisfaction. User satisfaction increases if IS has the ability to respond to potential problems in service accessibility and the ability to solve user problems and difficulties.

User satisfaction is an important step to ensure the success of an information system [36, 37]. Design that provides usefulness can affect the level of user satisfaction as a form of the success of information systems. The results of this study also indicate that system flexibility can increase user satisfaction. This is in line with the conclusions of previous studies $[55,56]$.
Accessibility refers to the extent to which a system can be used for most users without the need for modification. Kindfull application accessibility score is in the sufficient category. This happens because users have access difficulties. Some users do not have their own smartphones. Others have smartphones that don't match their specifications. This condition affects the quality of the system.

According to the findings of this study, the flexibility and ease of access to information systems have an impact on the system's quality. It is the degree to which the system is used in accordance with the user's needs, values, and experience. IS's adaptability allows it to provide appropriate, timely service and high-quality information.

As a result, in order to increase user satisfaction, designers, developers, and management must ensure that IS provides all of the functions that users expect. As a result, IS provided the level of service that users required to increase their satisfaction. Illias et al. stated that a reliable and easy to use system will provide satisfaction to its users [38]. A reliable system was showed when the system can continue to operate without experiencing significant interruptions (errors) for a long time.

\section{CONCLUSION}

The development of models to assess user competence, information system quality, and user satisfaction was successful in this study. To assess user competence, indicators of user knowledge and expertise are used. Flexibility and accessibility are indicators of the quality of an information system. Indicators of user satisfaction include content, format, accuracy, ease of use, and timeliness.

According to the research and discussion findings, it is necessary to increase user knowledge and expertise in order to improve system quality. This necessitates ongoing education. Competent users can maximize the application's functions and features.

As a result, information systems should be more accessible and designed with user needs in mind. The functions and services of the system should be user-friendly and adaptable. The goal of IS flexibility is to enable the system to easily adapt to changing needs, values, and user experiences. User satisfaction can be increased by SI with a high degree of flexibility and accessibility. They have the ability to provide information that is accurate, timely, and of high quality. As a result, system quality has the potential to improve user satisfaction

The kindfull digital character book is one of the information system applications used in education. Teachers and parents can use it as an alternative application to help children develop their character. They must collaborate to develop and monitor character education for children. If teachers and parents have the necessary knowledge and expertise, this application will be successful. The application's adaptable and user-friendly design makes it simple to use and access. As a result of the perceived ease of use, their satisfaction rises. They will continue to rely on it.

Because the findings of this study met the criteria for scientific research, it is suggested that other researchers conduct research using the same research method in a different unit of analysis. Additional research can be conducted by including variables, dimensions, and indicators. As a result, confidence in the research will grow, and the research's usefulness will be widely accepted. 
The coefficient of determination (R2) for IS quality in this study was 42.9 percent. This implies that many other factors influencing IS quality have not been investigated. Other considerations, such as top management support [57] and technological readiness [58], should be investigated further.

\section{REFERENCES}

[1] Marini, A. (2017). Character building through teaching learning process: Lesson in Indonesia. PONTE International Journal of Sciences and Research, 73(5): 177-182. http://dx.doi.org/10.21506/j.ponte.2017.5.43

[2] Jhon, W., Zubaidah, E., Mustadi, A. (2021). Challenges in the implementation of character education in elementary school: Experience from Indonesia. Ilkogretim Online, 20(1): 1351-1363. http://dx.doi.org/10.17051/ilkonline.2021.01.130

[3] Izzati, U.A., Bachri, B.S., Sahid, M., Indriani, D.E. (2019). Character education: Gender differences in moral knowing, moral feeling, and moral action in elementary schools in Indonesia. Journal for the Education of Gifted Young Scientists, 7(3): 547-556.

[4] Fitriati, A., Tubastuvi, N., Pratama, B.C., Anggoro, S. (2020). Study of Delone-Mclean information system success model: The relationship between system quality and information quality. Journal of Theoretical and Applied Information Technology, 98(03): 477-487.

[5] Isaac, O., Abdullah, Z., Ramayah, T., Mutahar, A.M. (2017). Internet usage within government institutions in Yemen: An extended Technology Acceptance Model (TAM) with internet self-efficacy and performance impact. Science International, 29(4): 737-747.

[6] Sabherwal, R., Jeyaraj, A., Chowa, C. (2006). Information system success: Individual and organizational determinants. Management Science, 52(12): $1849-1864$ https://doi.org/10.1287/mnsc.1060.0583

[7] Laumer, S., Maier, C., Eckhardt, A., Weitzel, T. (2016). Work routines as an object of resistance during information systems implementations: Theoretical foundation and empirical evidence. European Journal of Information Systems, 25(4): 317-343. https://doi.org/10.1057/ejis.2016.1

[8] Gable, G.G., Sedera, D., Chan, T. (2008). Reconceptualizing information system success: the IS impact measurement model. Journal of the Association for Information Systems, 9(7): 1-32. https://doi.org/10.17705/1jais.00164

[9] Ardito, C., Costabile, M.F., De Angeli, A., Lanzilotti, R. (2006). Systematic evaluation of e-learning systems: An experimental validation. NordiCHI '06: Proceedings of the 4th Nordic Conference on Human-Computer Interaction: Changing Roles, pp. 195-202. https://doi.org/10.1145/1182475.1182496

[10] Al-Okaily, A., Al-Okaily, M., Ai Ping, T., Al-Mawali, H., Zaidan, H. (2021). An empirical investigation of enterprise system user satisfaction antecedents in Jordanian commercial banks. Cogent Business \& Management, $\quad 8(1)$ : 1918847 https://doi.org/10.1080/23311975.2021.1918847

[11] DeLone, W.H., McLean, E.R. (1992). Information success the quest for dependent variable. Information System Research, 3(1): 60-95. https://doi.org/10.1287/isre.3.1.60

[12] DeLone, W.H., McLean, E.R. (2003). The Delone and Mclean model of information systems success: A ten year update. Journal of MIS, 19(4): 9-30. https://doi.org/10.1080/07421222.2003.11045748

[13] Petter, S., DeLone, W., McLean, E. (2013). Information systems success: The quest for the independent variables. J. of MIS, 29(4): 7-62. https://doi.org/10.2753/MIS07421222290401

[14] Ağaoğlu, M., Yurtkoru, E.S., Ekmekçi, A.K. (2015). The effect of ERP implementation CSFs on business performance: An empirical study on users perception. Procedia - Social and Behavioral Sciences, 210: 35-42. https://doi.org/10.1016/j.sbspro.2015.11.326

[15] Amoako-Gyampah, K. (2007). Perceived usefulness, user involvement, and behavioral intention: an empirical study of ERP implementation. Computers in Human Behavior, 23: 1232-1248. https://doi.org/10.1016/j.chb.2004.12.002

[16] Dezdar, S., Ainin, S. (2011). The influence of organizational factors on successful ERP implementation. Management Decision, 49(6): 911-926. https://doi.org/10.1108/00251741111143603

[17] Haddara, M., Moen, H. (2017). User resistance in ERP implementations: A literature review. Procedia Computer Science, 121: 859-865. https://doi.org/10.1016/j.procs.2017.11.111

[18] Juniora, C.H., Oliveiraa, T., Yanaze, M. (2019). The adoption stages (evaluation, adoption, and routinisation) of ERP systems with business analytics functionality in the context of farms. Computers and Electronics in Agriculture, $\quad$ 156: 334-348. https://doi.org/10.1016/j.compag.2018.11.028

[19] Ram, J., Corkindale, D., Wu, M. (2014). ERP adoption and the value creation: Examining the contributions of antecedents. Journal of Engineering and Technology Management, 33: 113-133. https://doi.org/10.1016/j.jengtecman.2014.04.001

[20] DeLone, W.H., McLean, E.R. (2016). Information systems success measurement. Foundations and Trends ${ }^{\circledR}$ in Information Systems, 2(1): 1-116. https://doi.org/10.1561/2900000005

[21] Vijai, J.P. (2018). Examining the relationship between system quality, knowledge quality and user satisfaction in the success of knowledge management system: An empirical study. International Journal of Knowledge $\begin{array}{lll}\text { Management } & \text { Studies, } & \text { 9(3): }\end{array}$ https://doi.org/10.1504/ijkms.2018.094211

[22] Doll, W.J., Torkzadeh, G. (1988). The measurement of end-user computing satisfaction. MIS Quarterly, 259-74. https://doi.org/10.2307/248851

[23] Boadu, R.O., Agyei-Baffour, P., Edusei, A.K. (2019). Using quality improvement process to enhance health staff confidence and competence in health information system tasks in the Ejisu Juaben Municipal Health Directorate, Ghana. Journal of Information Sciences and Computing Technologies (JISCT), 8(1): 781-793. Retrieved from http://scitecresearch.com/journals/index.php/jisct/article /view/1673.

[24] Wahyudi, I. (2016). Do risk controls and user's competence affecting accounting information system quality? IJABER, 14(3): 1561-1569.

[25] Garg, P. (2010). Critical failure factors for enterprise 
resource planning implementations in Indian retail organizations: An exploratory study. Journal of Information Technology Impact, 10(1): 35-44.

[26] Oz, E. (2009). Management Information Systems. 6thed. USA: Cangage Learning.

[27] Koo, C., Chung, N., Kim, H.W. (2015). Examining explorative and exploitative uses of smartphones: A user competence perspective. Information Technology \& People, 28(1): 133-162. https://doi.org/10.1108/itp-042013-0063

[28] Spencer, L.M., Spencer, S.M. (1993). Competence at Work, Canada: John Wiley \& Sons, Inc.

[29] Kessler, R. (2008). Competency-Based Performance Reviews. New Jersey: The Career Press, Inc.

[30] Mathis, R.L., Jackson, J.H. (2011). Human Resource Management. 13th ed. Mason: Cengage Learning.

[31] Taylor, I. (2007). A Practical Guide to Assessment Centres and Selection Methods. London: Kogan Page.

[32] Gomes-Mejia, L.R., Balkin, D.B., Cardy, R.L. (2012). Managing Human Resources. New Jersey: Pearson Education, Inc. Prentice Hall.

[33] Stair, R.M., Reynold, G.W. (2010). Principles of Information System. A Managerial Approach. 9th ed. Boston: Cengage Learning.

[34] Heidman, M. (2008). The role of management accounting systems in strategic sensemaking. Germany: Deutscher Universitäts-Verlag Wiesbaden.

[35] Romney, B.M., Steinbart, J.P. (2012). Accounting Information System. 12th ed. Pearson Education.

[36] Puspitawati, L. (2016). The analysis of effectiveness measurement in accounting information systems through competence factor of information system user. IJABER, 14(1): 313-339.

[37] Ajoye, M. (2014). Information systems user satisfaction: a survey of the postgraduate school portal. University of Ibadan. Nigeria. Library Philosophy and Practice. https://digitalcommons.unl.edu/libphilprac/1192/.

[38] Illias, A., Mohammad, R.Y., Mohammad, Z.A.R., Rahida, A.R. (2007). The study of EUCS on computerised accounting system among Labuan Government Sectors a case study in the responsibility centres. Labuan E-Journal of Muamalat and Society, 11: $1-14$.

[39] Laudon, K.C., Laudon, J.P. (2012). Management Information System. Managing the Digital Firm. 12th ed. New Jersey: Pearson Prentice Hall.

[40] Hair, Jr.J.F., Hult, G.T.M., Ringle, C.M., Starstedt, M. (2014). A Premier on Partial Least Squares Structural Equational Modeling. California: Sage Publication. Inc.

[41] Nokali, N., Bachman, H., Drzal, E. (2010). Parent involvement and children's academic and social development in elementary school. Child Development, 81(3): 988-1005. https://doi.org/10.1111/j.14678624.2010.01447.x

[42] Utami, S.S., Egok, A.S., Valen, A. (2020). Development of thematic worksheet based on character education for fifth graders schools. Journal of Educational Research and Evaluation, 9(1): 8-14.

[43] Topor, D., Keane, S., Shelton, T., Calkins, S. (2010). Parent involvement and student academic performance: a multiple mediational analysis. J Prev Interv Community, 38(3): 183-197. https://doi.org/10.1080/10852352.2010.486297

[44] Elias, M.J. (2009). Social-emotional and character development and academics as a dual focus of educational policy. Educational Policy, 23(6): 831-846. https://doi.org/10.1177/0895904808330167

[45] Anggoro, S., Sopandi, W., Sholehuddin, M. (2017). Influence of joyful learning on elementary school students' attitudes toward science. Journal of Physics: Conference $\quad$ Serie, $\quad 812(1)$ : 012001. https://doi.org/10.1088/1742-6596/812/1/012001

[46] Kethineni, S., Kouassi, S., Columb, C., Gay, K. (2018). Effectiveness of parent-engagement programs to reduce truancy and juvenile delinquency: A systematic review. Campbell Collaboration.

[47] Park, S., Holloway, S. (2016). The effects of schoolbased parental involvement on academic achievement at the child and elementary school level: A longitudinal study. The $\mathrm{J}$ of Educational Research, 110: 1-16. https://doi.org/10.1080/ 00220671.2015.1016600

[48] LaRocque, M., Kleiman, I., Darling, S.M. (2011). Parental involvement: The missing link in school achievement. Preventing School Failure, 55(3): 115-122. https://doi.org/10.1080/10459880903472876

[49] Sedera, D., Dey, S. (2013). User expertise in contemporary IS: Conceptualization, measurement, and application. Information \& Management, 50: 621-37. https://doi.org/10.1016/j.im.2013.07.004

[50] Madapusi, A. (2014). The influence of technical competence factors in ERP system implementations. Journal of Applied Business and Economics, 16(2): $27-$ 39.

[51] Eby, L., Adams, D., Russell, J., Gaby, S. (2000). Perception of organizational readiness for change: factors related to employee's reactions to the implementation of team-based selling. Human Relation, 53(3): 419-28. https://doi.org/10.1177/0018726700533006

[52] Venkatesh, V., Morris, M.G., Davis, G.B., Davis, F.D. (2003). User acceptance of information technology: Toward a unified view. MIS Quarterly, 27(3): 425-478. https://doi.org/10.2307/30036540

[53] Billipp, S.H. (2001). The psychosocial impact of interactive computer use within a vulnerable elderly population: a report on a randomized prospective trial in home health care setting. Public Health Nursing, 18(2): 138-145. https://doi.org/10.1046/j.15251446.2001.00138.x

[54] White, J., Weatherall, A. (2000). A grounded theory analysis of older adults and information technology. Educational Gerontology, 26(4): 371-387. https://doi.org/10.1080/036012700407857

[55] Chiu, C.M., Hsu, M.H., Sun, S.Y., Lin, T.C., Sun, P.C. (2005). Usability, quality, value, and e-learning continuance decisions. Comp. \& Education, 45: 399-416. https://doi.org/10.1016/j.compedu.2004.06.001

[56] Isaac, O., Abdullah, Z., Ramayah, T., Mutahar, A.M., Alrajawy, I. (2018). Integrating user satisfaction and performance impact with Technology Acceptance Model (TAM) to examine the internet usage within organizations in Yemen. Asian Journal of Information Technology, 17(1): 60-78.

[57] Fitriati, A., Susanto, A. (2017). The accounting information system quality improvement through internal control and top management support effectiveness. Journal of Theoretical and Applied Information Technology, 95(19): 5003-5011. 
[58] Blut, M., Wang, C. (2020). Technology readiness: A meta-analysis of conceptualizations of the construct and its impact on technology usage. Journal of the Academy of Marketing Science, 48: 649-669. 